\title{
Yield response of cucumber to deficit irrigation in greenhouses
}

\author{
A. M. Al-Omran \& I. I. Louki \\ Soil Science Department, King Saud University Riyadh, Saudi Arabia
}

\begin{abstract}
Water is the most important resource and limiting factor for agricultural development. In Saudi Arabia, the agricultural sector consumes more that $85 \%$ of the total annual water consumption. Recently, the demand on water for agriculture has increased which has resulted in water shortages in many regions of the country particularly the old oasis. Therefore, methods which increase water use efficiency (WUE) and reduce water excessive amount of water applied are of importance for conserving water. In this context, deficit irrigation can play an important role in increasing WUE and reduced amount of irrigation. Deficit irrigation is a strategy, which allows a crop to sustain some degree of water deficit during certain stages of crops or the whole season without a significant reduction in yield in order to reduce irrigation. In this study, a series of greenhouse and open field experiments were conducted using a deficit irrigation program on cucumber crops under drip irrigation during (2008-2010) growing seasons. Water was added at $40,60,80,100 \%$ of ETc in addition to the traditional methods used by farmers in the region. The objective of the study was to determine the crop response factor (ky) and WUE of cucumber crop using a deficit irrigation program at different stages of growth and through the entire growing season. Results indicated that a cucumber could stand the shortage of water during the growth and crop response $(\mathrm{Ky})$ values ranged between $(0.70$ 0.98); however, the amount of water used was much lower than that of traditional methods used by farmers in the region.
\end{abstract}

Keywords: deficit irrigation, greenhouse grown cucumber, water use efficiency, drip irrigation, crop water requirement. 


\section{Introduction}

The ecosystem of arid regions of Saudi Arabia is impoverished by scarcity of water resources and of the predominance of sandy soil, which consists of more than $45 \%$ of the cultivated soils (Bashour et al. [1]). Sandy soils are particularly critical for water management due to their low water-holding capacity, high infiltration rate and low organic matter, which may induce low water use efficiency (Al-Omran et al. [2]). The water shortage and increasing demand for water in agriculture and other sectors compel the need for the adoption of irrigation strategies in Saudi Arabia from open field to greenhouse under drip irrigation. This may allow saving irrigation water for agricultural sector (AlOmran et al. [3]). An approach to attain the objective of saving water and increasing water use efficiency (WUE) is through using deficit irrigation program (DI) where crops are deliberately allowed some degree of deficit irrigation through the whole growth stage or at certain stages of the growth (Kirda [4]). Deficit irrigation generally refers to fully irrigated crops where water is reduced or withheld during certain growth stages.

The adoption of irrigation deficit required the knowledge of crop evapotranspiration (ETc), crop response to water deficit, critical stages of growth under water deficit and economic impacts of yield reduction (Pereira et al., 2002)[5]. The research on deficit irrigation has been widely investigated as valuable strategy mainly in arid regions (Pereira et al. [5]). Mao et al. [6] reported on their study on the effect of deficit irrigation on yield and water use of greenhouse grown cucumber in China that WUE decreased with the increase of irrigation water applied from stem fruiting to the end. However, WUE was ascending with the increase of irrigation water from cucumber field setting to first fruit repining.

The work on yield response factor $(\mathrm{Ky})$ to water for many crops have been documented in the literature (Kirda [4]; Moutonnet [7]) where crops have a value of Ky lower than 1 can tolerate the water deficit. On the contrary, crops showing a Ky greater than one show a yield decrease more than proportional to the applied ET decrease, which means that the crop might not tolerate any irrigation deficit. Ayas and Domirtas [8] reported that Ky value for cucumber grown in Turkey ranged between $(0.196-1.31)$ depend on the water stress growth stage, while Amer et al. [9] concluded that these values ranged between $0.71-0.85$ in a field experiment in Egypt. The value of Ky for green beans was 1.23, while the values for safflower and eggplant were 0.97 and 1.37 , respectively (Lovelli et al. [10]).

The deficit irrigation strategy has received very little attention in the agricultural sector in Saudi Arabia and therefore, the objectives of this study were to determine the water requirement for cucumber grown under greenhouse with drip irrigation. In addition, the determination of the effect of deficit irrigation at different stages of growth of cucumbers on yield and water use efficiency. 


\section{Materials and methods}

Field experiments were carried out at the greenhouse complex at Almohous Farm, 120 km northwest of Riyadh, Saudi Arabia, from February, 2007 till April, 2010 for a total of 12 experiments. Selected properties of the soil and irrigation water were determined by standard procedure (Page et al. [11]). Electrical conductivity of the soil, $\mathrm{pH}, \mathrm{CaCO}_{3}, \mathrm{Sand} \%$ and clay $\%$ are $3.6 \mathrm{dS} / \mathrm{m}, 7.9,18 \%$, $84 \%$, and $10 \%$, respectively. The layout of the experiment was completely randomized design with four replicates. Irrigation treatments consist of five level of ETc $(30,40,60,80$, and $100 \%$ of ETc) in additional to traditional practice by farmers. At 60 and $80 \%$ treatments, deficits irrigation tested at different growth stages (development, med, and late stages of the growth) for a total of 14 treatments at each experiments as shown in Table 1. The cultivar of "Bazz" of

Table 1: $\quad$ Irrigation treatment combination of each experiment.

\begin{tabular}{|c|c|c|c|c|c|}
\hline Treatment & $\begin{array}{c}\text { Initial } \\
\text { St. }\end{array}$ & $\begin{array}{l}\text { Develop. } \\
\text { St }\end{array}$ & $\begin{array}{l}\text { Mid. } \\
\text { St. }\end{array}$ & $\begin{array}{l}\text { Late. } \\
\text { St. }\end{array}$ & Description \\
\hline $\mathrm{T}_{1}-100$ & 0 & 0 & 0 & 0 & $\begin{array}{l}\text { Full irrigation During the season }(100 \% \text { of } \\
\left.\mathrm{ET}_{\mathrm{m}}\right) \text {. }\end{array}$ \\
\hline $\mathrm{T}_{2}-80-0$ & 1 & 1 & 1 & 1 & $\begin{array}{l}80 \% \text { of } \mathrm{ET}_{\mathrm{m}} \text { irrigation during the season has } \\
\text { given. }\end{array}$ \\
\hline $\mathrm{T}_{3}-80-1$ & 0 & 1 & 1 & 1 & $\begin{array}{l}\text { A full irrigation up to the end of } 1^{\text {st }} \text { stage, } \\
\text { then } 80 \% \text { of } \mathrm{ET}_{\mathrm{m}} \text { for remained stages. }\end{array}$ \\
\hline $\mathrm{T}_{4}-80-2$ & 1 & 0 & 1 & 1 & $\begin{array}{l}\text { A full irrigation at the development stage, } \\
\text { then } 80 \% \text { of } \mathrm{ET}_{\mathrm{m}} \text { restoration for remained } \\
\text { stages. }\end{array}$ \\
\hline $\mathrm{T}_{5}-80-3$ & 1 & 1 & 0 & 1 & $\begin{array}{l}\text { A full irrigation at the mid stage, then } 80 \% \\
\text { of } \mathrm{ET}_{\mathrm{m}} \text { restoration for another stage. }\end{array}$ \\
\hline $\mathrm{T}_{6}-80-4$ & 1 & 1 & 1 & 0 & $\begin{array}{l}\text { A full irrigation at the late stage, then } 80 \% \\
\text { of } \mathrm{ET}_{\mathrm{m}} \text { restoration for remained stages. }\end{array}$ \\
\hline $\mathrm{T}_{7}-60-0$ & 1 & 1 & 1 & 1 & $60 \%$ of $\mathrm{ET}_{\mathrm{m}}$ irrigation during the season. \\
\hline $\mathrm{T}_{8}-60-1$ & 0 & 1 & 1 & 1 & $\begin{array}{l}\text { A full irrigation up to the end of } 1^{\text {st }} \text { stage, } \\
\text { then } 60 \% \text { of ETm for remained stages. }\end{array}$ \\
\hline $\mathrm{T}_{9}-60-2$ & 1 & 0 & 1 & 1 & $\begin{array}{l}\text { A full irrigation at the development stage, } \\
\text { then } 60 \% \text { of } \mathrm{ET}_{\mathrm{m}} \text { restoration for remained } \\
\text { stages. }\end{array}$ \\
\hline $\mathrm{T}_{10}-60-3$ & 1 & 1 & 0 & 1 & $\begin{array}{l}\text { A full irrigation at the mid stage, then } 60 \% \\
\text { of } \mathrm{ET}_{\mathrm{m}} \text { restoration for remained stages. }\end{array}$ \\
\hline $\mathrm{T}_{11}-60-4$ & 1 & 1 & 1 & 0 & $\begin{array}{l}\text { A full irrigation at the late stage, then } 60 \% \\
\text { of } \mathrm{ET}_{\mathrm{m}} \text { restoration for remained stages. }\end{array}$ \\
\hline $\mathrm{T}_{12}-40$ & 1 & 1 & 1 & 1 & $\begin{array}{l}40 \% \text { of } \mathrm{ET}_{\mathrm{m}} \text { irrigation during the season has } \\
\text { given.. }\end{array}$ \\
\hline $\mathrm{T}_{13}-30$ & 1 & 1 & 1 & 1 & $\begin{array}{l}30 \% \text { of } \mathrm{ET}_{\mathrm{m}} \text { irrigation during the season has } \\
\text { given.. }\end{array}$ \\
\hline $\mathrm{T}_{14-}$ Trad & \multicolumn{4}{|c|}{ Traditional Irrigation } & $\begin{array}{l}\text { just counting irrigation water from a local } \\
\text { traditional irrigation system by a water } \\
\text { meter. }\end{array}$ \\
\hline
\end{tabular}


cucumber (Cucumbis sativus L.) was used for the experiments. The big main line is $63 \mathrm{~mm}$ in diameter. The used of main lines tubing (16 $\mathrm{mm}$ in diameter), the length of each line is $17 \mathrm{~m}$ with emitters built in at $0.5 \mathrm{~m}$ spacing with distance between row of $1 \mathrm{~m}$. Furthermore, gauges were installed for measuring the amount of water applied for each treatment as shown in Figure 1.

Irrigation scheduling methods based on pan evaporation are widely used with different ETc percentage because it is easy to use and its availability (Kirda et al. [12]; Simsek et al. [13]). Crop evapotranspiration (ETc) calculated from the following equation:

$$
\mathrm{ETc}=\mathrm{Eo} \mathrm{Kp} \mathrm{Kc}
$$

where ETc is the maximum daily ET in mm; Eo is the evaporation from class A pan in $\mathrm{mm}$; $\mathrm{Kp}$ is the pan coefficient, calculated according to Allen et al. [14], and ranged from $(0.70-0.88)$; Kc is the crop coefficient, ranging between $(0.57-$ 1.26) for different stages of the growth.

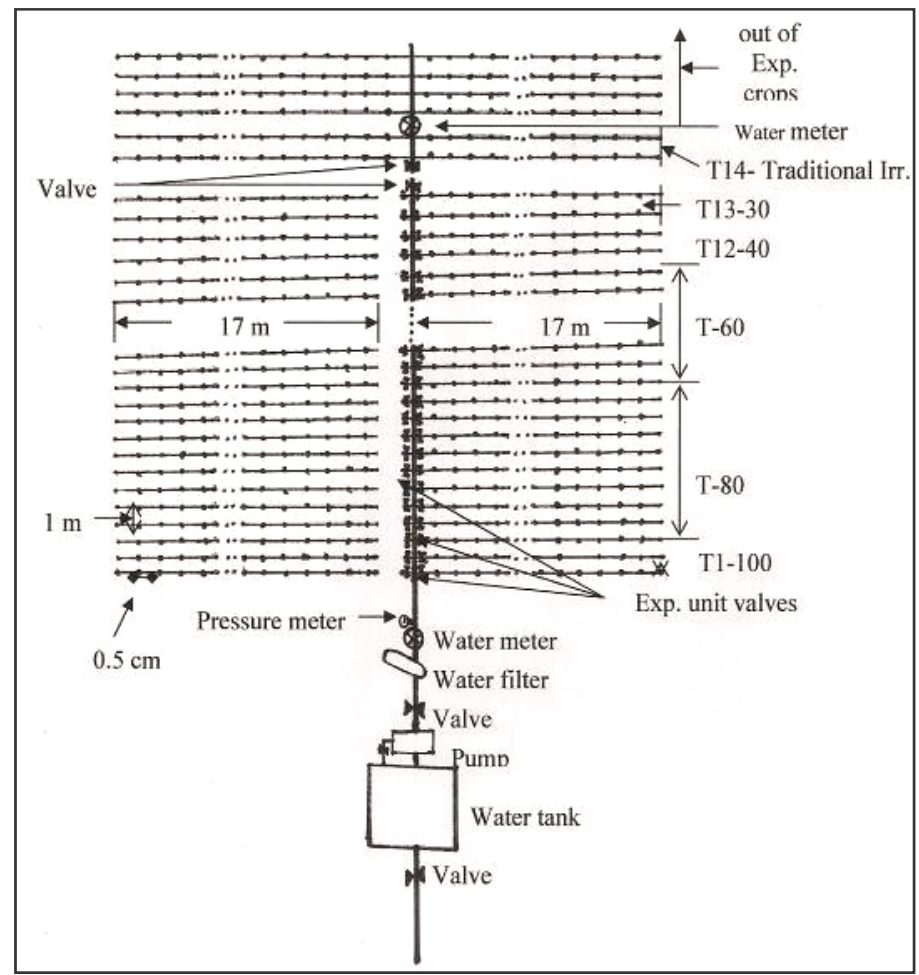

Figure 1: $\quad$ Layout of the experiment with all treatments and spacing. 
Water use efficiency or crop water productivity as reviewed by Molden [15] is generally defined as the ratio crop yield $(\mathrm{Kg})$ to volume of water applied $\left(\mathrm{m}^{3}\right)$ to produce the yield:

$$
\text { WUE }=\text { Yield/ water applied }
$$

The relationship between crop yield and water application is called water production function (WPF). The WPF becomes curvilinear as more of applied water goes to drainage or loss. A useful way to express the water production function is on a relative basis, where actual yield (Ya) is divided by maximum yield $(\mathrm{Ym})$ and actual evapotranspiration (ETa) is divided by crop evapotranspiration $(\mathrm{ETc})$. The relationship between evapotranspiration deficit $(1-(\mathrm{ETa} / \mathrm{ETc}))$ and yield depression $(1-(\mathrm{Ya} / \mathrm{Ym}))$ is always linear (Doorenbos and Kassam [16]), with a slope called the yield response factor of the crop (ky). This relationship is expressed by the following equation:

$$
(1-(\mathrm{Ya} / \mathrm{Ym}))=\operatorname{Ky}(1-(\mathrm{ETa} / \mathrm{ETm}))
$$

\section{Results and discussion}

The results of crop evapotranspiration (ETc) at each treatment and water applied (AW) are presented in Table 2. The calculated and the exact applied water are very close. The irrigation treatments were started measuring of evaporation from class A pan. The maximum amount of water applied to the crop was $332 \mathrm{~mm}$ for the $\mathrm{T}_{1}-100$ treatment while the minimum water applied was $100 \mathrm{~mm}$ for $\mathrm{T}_{13}$ treatment, and $600 \mathrm{~mm}$ for traditional practice by the farmers in the region. The calculated ETc ranged between $95-316 \mathrm{~mm}$ for the different treatment. Water use efficiency (WUE) and water productivity (WP) values increased when water amount decreased with exception of the traditional irrigation, these values decreased to 45.6 and $24 \mathrm{~kg} / \mathrm{m}^{3}$, respectively. The highest values at much stressed treatment $\left(\mathrm{T}_{13}-30\right)$. In this study, irrigation treatments significantly affected the yield ranging between $7-14.4 \mathrm{~kg} / \mathrm{m}^{2}$; however decreasing irrigation water to level of $80 \%$ of ETc did not affect the growth. An attempt was made to establish a relationship between water consumed and yield Figure 2. Linear relationship was observed between crop evapotranspiration ETc and yield (Y) with equation for the relationship as $\mathrm{Y}=0.0303 \mathrm{ETc}+4.68$ with $\mathrm{r}^{2}=0.95$. A polynomial relationship was determined between (Y) and (AW) Fig, 2. Using the crop water production function (CWPF) equation to predict maximum yield for all the experiments. The predicted maximum yield was $15.2 \mathrm{~kg} / \mathrm{m}^{2}$. The equation for the relationship was $\mathrm{Y}=-6 \mathrm{E}-05 \mathrm{AW}^{2}+0.056 \mathrm{AW}+1.95$ with $\mathrm{r}^{2}=0.96$ (Fig. 3). In the study of 12 repeated experiments at different time of the year for four years. Treatment $T_{1}-100$ had the highest yield; however treatments $T_{3}, 4,5,6-$ 80 ( $20 \%$ of deficit irrigation) gave a good marketable yield with saving of water, fertilizers and pesticide. However, water productivity (WP) represents the 
522 Water Resources Management VI

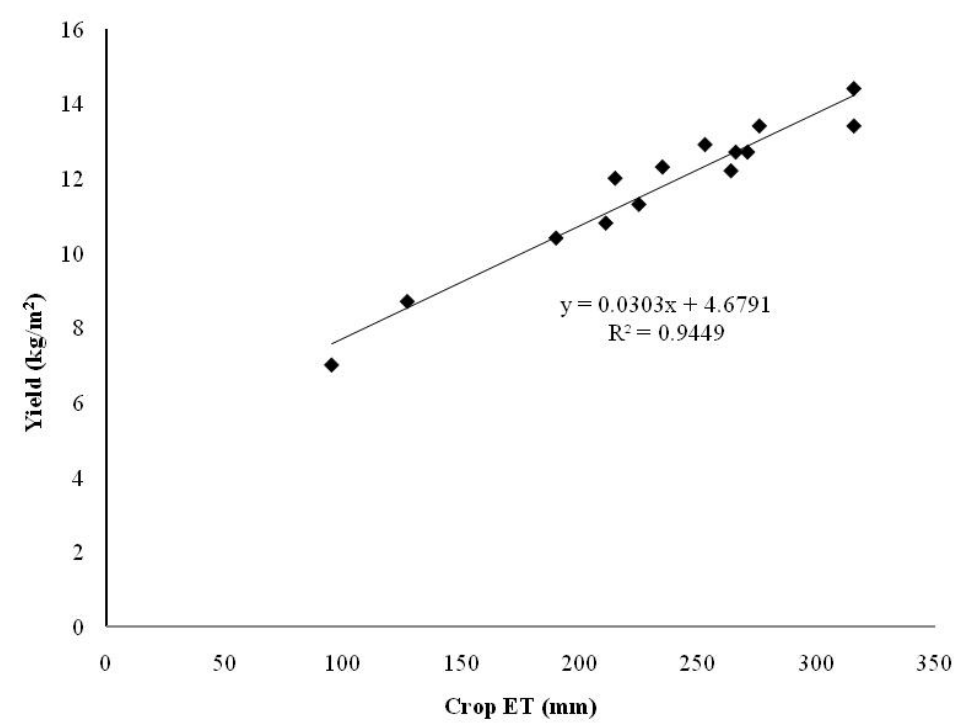

Figure 2: $\quad$ The relationship between crop ET and yield.

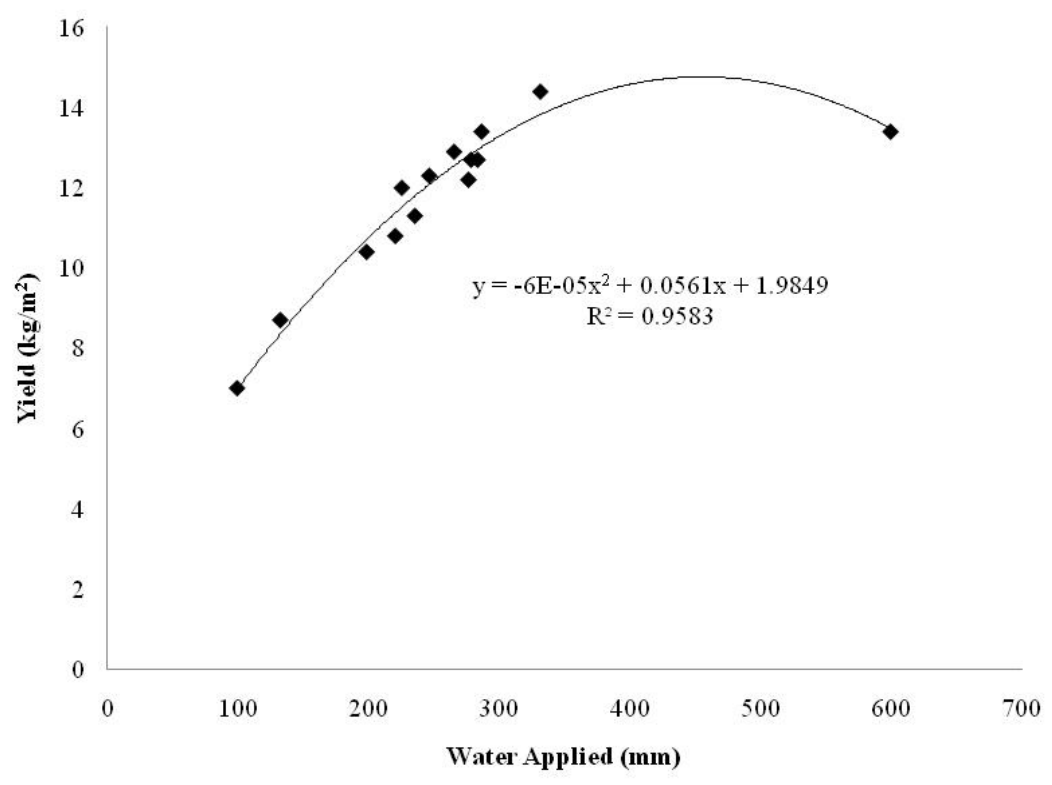

Figure 3: The relationship between applied water and yield. 
productivity of water related to the crop yield. The WP increased with decreasing the amount of water applied to the field from $45 \%$ to $70 \%$. While the WP of the traditional irrigation treatment get the lowest value of $24 \%$. It was evident that the over irrigation as of traditional method resulted in lower water productivity. Lack of irrigation as of treatments $T_{12}-40$ and $T_{13}-30$ caused very high water productivity but with very poor yield in both quantity and quality.

Crop yield response factor $(\mathrm{Ky})$ was determined for the different treatment of deficit irrigation. Ky indicates al linear relationship between the relative reduction in water consumed and relative reduction in yield. Seasonal crop response factor for different treatment through the growth with an average value of 0.70 (Figure 4). In conclusion, deficit irrigation at $20 \%$ of ETc was more effective in saving irrigation water with a good marketable yield compare to $100 \%$ of ETc treatment and traditional irrigation practice by farmers in the region. In addition, deficit drip irrigation saved the amount of fertilizers and pesticides used in farms.

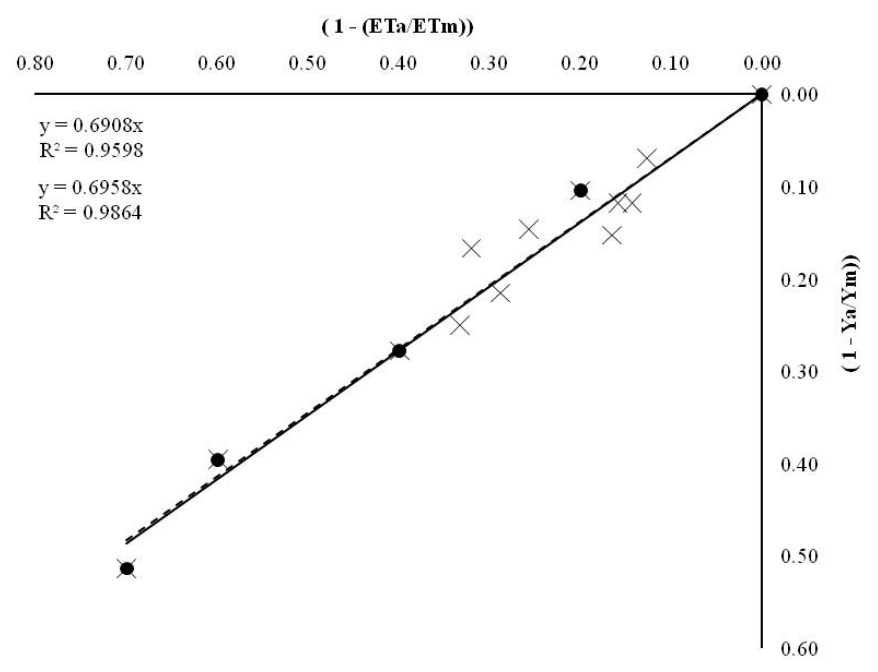

Figure 4: $\quad$ Relative yield response to relative ETc deficit.

\section{References}

[1] Bashour I. I., A.S. Al-Mashhady, J. Devi Prasad, T. Miller and M. Mazroa. Morphology and composition of some soils under cultivation in Saudi Arabia. Geoderma, 29 (4): 327-340. 1983.

[2] Al-Omran, A.M., A. S. Sheta, A. M. Falatah and A. R. Al-Harby. Effect of Drip Irrigation on Squash (Cucurbita pepo) Yields and Water Use Efficiency in Sandy Calcareous Soils Amended with Clay Deposits. Agricultural Water Management. 73 (1):43-55. 2005. 
[3] Al-Omran, A.M., A. R. Al-Harbi, M. A. Wahb-Allah, M. Nadeem and A. Eleter. Impact of irrigation water quality, irrigation systems, irrigation rates and soil amendments on tomato production in sandy calcareous soil. Turk J. Agric. For. 34: 59 - 73. 2010.

[4] Kirda, C. Deficit irrigation scheduling based on plant growth stages showing water stress tolerance. In Deficit irrigation practices. C. Kirda, P. Moutonnet, C. Hera and D.R. Nielsen (eds).Water Report \#22 FAO, Rome. 2000.

[5] Pereira, L.S., T. Oweis and A. Zairi. Irrigation water management under water scarcity. Agric. Water Manage. 57:175-206. 2002.

[6] Mao, X., M. X. Wang; C. Liu, Z. Hou and J. Shi. Effects of deficit irrigation on yield and water use of greenhouse grown cucumber in the North China Plain. Agricultural water management. 61 (3): 219-228. 2003.

[7] Moutonnet, P. Yield Response to Field Crops to Deficit Irrigation In Deficit irrigation practices. C. Kirda, P. Moutonnet, C. Hera and D.R. Nielsen (eds).Water Report \#22 FAO, Rome. 2000.

[8] Ayas, B. and C. Demirtas. Deficit irrigation effects on cucumber (Cucumis sativus L. Maraton) yield in unheated greenhouse condition. J. Food, Agric. And Environ. 7(3\&4):645-649. 2009.

[9] Amer, K.H., S.A. Midan, J, Hatfield. Effect of deficit irrigation and fertilization on cucumber. Agronomy J. 101(6): 1556-1564. 2009.

[10] Lovelli, S.; M. Perniola, A. Ferrara, T. D. Tammaso. Yield response factor to water $(\mathrm{Ky})$ and water use efficiency of Carthamus tinctorius L. and Solaum melongeual. Agric. water Mange. 92: 73-80. 2007.

[11] Page, A.L., R.H. Miller, and D.R. Keeney. Methods of soil analysis, part 2. chemical and microbiological properties. Amer. Soc. of Agron. Madison, Wisconsin, USA. 1982.

[12] Kirda, C. , M. Cetin, Y. Dasgan, S. Topcu, H. Kaman, B. Ekici, M. R. Derici and A. I. Ozguven. Yield response of greenhouse grown tomato to partial root drying and conventional deficit irrigation. Agricultural Water Management. 69:(3), 191-201. 2004.

[13] Simsek, M., T. Tonkaz, M. Kacira, N. Comlekcioglu and Z. Dogan. The Effects of Different Irrigation Regimes on Cucumber (Cucumbis sativus L.) Yield and Yield Characteristics under Open Field Conditions Science Direct, Agricultural Water Management. 73 (3): 173-191. 2004.

[14] Allen, R.G., L.S. Pereira, D. Raes and M. Smith. Crop evapotranspiration guidelines for computing crop water requirements. FAO Irrigation and Drainage paper \#56. 1998.

[15] Molden D. Comprehensive assessment of water management in agriculture series, International water management institute. Pelawata, Battarnulla, Sri Lanka. 2003.

[16] Doorenbos J \& Kassam AH. Yield response to water. FAO Soils Bulletin 33. FAO, Rome. 1986. 